Науковий вісник НлТУ України Scientific Bulletin of UNFU https://nv.nltu.edu.ua https://doi.org/10.36930/40310407

Article received $20.08 .2021 \mathrm{p}$. Article accepted 09.09.2021 p. UDC 581.5:628.511.4
ISSN 1994-7836 (print)

ISSN 2519-2477 (online)

$@ \bowtie$ Correspondence author

M. P. Kurnytska

kurnytskam@gmail.com

К. В. Мирончук'1, М. П. Курницька ${ }^{2}$

${ }^{1}$ Чернівецький національний університет ім. Юрія Федьковича, м. Чернівиі, Украйна

${ }^{2}$ Національний лісотехнічний університет України, м. Львів, Україна

\title{
ПИЛОЗАХИСНА ФУНКЦІЯ ЖИВОПЛОТІВ НА ПРИКЛАДІ УРБОЕКОСИСТЕМ ЧЕРНІВЕЦЬКОЇ ОБЛАСТІ
}

\begin{abstract}
Зелені насадження сучасних урбанізованих територій виконують важливі середовищетвірні та середовищезахисні функції, серед яких можна виділити їх пилозахисну здатність. Живоплоти, як невід'ємні елементи міського і позаміського озеленення, роблять свій вагомий внесок не тільки в естетизацію середовища, але й у вирішення його екологічних проблем. Досліджено пилозатримувальну здатність живих огорож, сформованих з найпоширеніших для них видів деревних рослин: свидини білої (Cornus alba (L.) Opiz.), граба звичайного (Carpinus betulus L.) та пухироплідника калинолистого (Physocarpus opulifolia L.), що ростуть на території міст і селищ Чернівецької області під дією різного антропогенного навантаження. За результатами порівняльного аналізу акумулювання пилу на листках досліджуваних живоплотів з'ясовано, що його кількість закономірно збільшується паралельно до погіршення екологічних умов від I до IV ЕФП. Встановлено, що за умов найменшого урбогенного впливу досліджені живоплоти осаджують від 0,0001 до 0,00017 мг/см² пилу, а на їх листках вздовж завантажених транспортом міських вулиць кількість пилу збільшується у 3,1-4,3 раза. Виявлено високий рівень седиментації пилу на листкових пластинках усіх досліджуваних видів, особливо Carpinus betulus, оскільки вид має складну фактуру поверхні листкової пластинки. Зауважено, що кількість пилу на фітомасі живоплотів залежить від типу прилеглого до насадження надгрунтового вкриття. Запропоновано асортимент газостійких видів для формування живоплотів у цьому регіоні з найкращим пилозатримувальним ефектом. Розроблено практичні рекомендації з покращення функціональної здатності живих огорож, основними 3 яких для $25 \%$ дослідних живоплотів є оновлення, для $67 \%$ - доповнення у місцях втрати структурних одиниць, здебільшого - формувальні та санітарні обрізування. Узагальнено доцільність ширшого запровадження живоплотів у систему озеленення населених пунктів як індикаторів техногенного забруднення і потужного пилового бар'єру.
\end{abstract}

Ключові слова: жива огорожа; пило затримання; седиментація; урбанізоване середовище; урбогенний вплив.

\section{Вступ / Introduction}

Найскладнішою i найпоширенішою проблемою функціонування сучасних міст $є$ забруднення атмосфери і його негативний вплив не тільки на довкілля, але і якість життєвого комфорту. У великих населених пунктах транспорт $є$ основним джерелом шкідливих викидів, частка яких становить близько 80 \% [16]. На думку Ганаба Д. В. (2015), пил є одним із потужних забруднювачів атмосферного повітря. Його концентрація у звичному міському середовищі становить $0,1-0,2 \mathrm{Mг} / \mathrm{m}^{3}$, а у великих промислових центрах - не нижча за $0,5 \mathrm{m \Gamma} / \mathrm{m}^{3}$. Пил має здатність переноситися на великі відстані від місць його утворення. Джерела пилу можуть бути як природного походження, так і індустріального.

Особливе місце у питаннях фільтрації та оздоровлення атмосферного повітря урбоекосистем належить зеленим насадженням, які, окрім цього, виконують чимало інших важливих функцій. Встановлено, що рослини можуть притягувати на поверхню листя 6-76 т пилових частинок з га площі (залежно від дендроскладу)
[19]. Причому влітку вони вловлюють до 86 \% пилу, а взимку очищають повітря на 37,4 \% порівняно з не озелененими поверхнями.

Відомо, що пилозатримувальна здатність дерев і кущів залежить від низки чинників, найважливішими 3 яких є видові особливості рослин (розміри і щільність крон, анатомо-морфологічна будова листкової пластинки, іiі розміри, структура поверхні), кліматичні умови, вік рослин, пора року та характеристики насадження [1, $6,9]$. Оскільки переважна більшість часток пилу міститься у приземному горизонті, то найбільше їх осідає на нижніх частинах крон і на кущах $[4,15,23]$.

Живоплоти - поширений елемент садово-паркових об'єктів сучасного міста, який відомий своїми санітарно-гігієнічними, ладшафтно-планувальними та архітектурно-художніми функціями. Водночас захисним властивостям живоплотів, зокрема пилозахисній дії, присвячено небагато наукових досліджень. Тому актуальним $\epsilon$ розгляд питань, пов'язаних зі здатністю живоплотів до фільтрації пилу, особливо вздовж магістральних транспортних шляхів великого міста.

\section{Інформація про авторів:}

Мирончук Катерина Василівна, канд. с.-г. наук, асистент, кафедра ботаніки, лісового та садово-паркового господарства. Email: k.myronchuk@chnu.edu.ua; https://orcid.org/0000-0001-5462-6226

Курницька Марта Петрівна, канд. с.-г. наук, доцент, кафедра ландшафтної архітектури, садово-паркового господарства та урбоекологіï. Email: kurnytskam@gmail.com; https://orcid.org/0000-0003-1059-9857

Цитування за ДСту: Мирончук К. В., Курницька М. П. Пилозахисна функція живоплотів на прикладі урбоекосистем Чернівецької області. Науковий вісник НлтУ України. 2021, т. 31, № 4. С. 48-53.

Citation APA: Myronchuk, K. V., \& Kurnytska, M. P. (2021). Dust retention function of hedges: the case study of urban ecosystems in Chernivtsi region. Scientific Bulletin of UNFU, 31(4), 48-53. https://doi.org/10.36930/40310407 
Об'єкт дослідження - живоплоти смт Берегомет та м. Чернівці, що ростуть в умовах I - IV еколого-фітоценотичного поясу (ЕФП) [13].

Предмет дослідження - пиловловлювальна здатність живоплотів, створених 3 основних традиційних для них видів кущів.

Мета роботи - встановлення пиловловлювальної ефективності різновидових живоплотів, підбір перспективних видів і методів вдосконалення структури живоплотів для покращення екологічного стану урбогенних територій.

Для досягнення зазначеної мети визначено такі основні завдання дослідження: проаналізувати пиловловлювальні функцій різновидових живоплотів, що зростають в умовах різного урбогенного навантаження на прикладі Чернівців і населених пунктів Чернівецької області; підібрати перспективні види деревних рослин для формування пилозахисних живоплотів; розробити рекомендації щодо екологічної ефективності наявних живоплотів.

Наукова новизна отриманих результатів дослідження - вперше в умовах Буковинської урбоекосистеми досліджено пиловловлювальну ефективність живоплотів залежно від умов місцезростання та видових особливостей рослин. Встановлено основні критерії якісної роботи пилового бар'єру - живоплоту, які залежать як від структурних особливостей об'єкта, екологічних і кліматичних умов території, так і особливостей догляду.

Практична значущість результатів дослідження отримані результати роботи та запропоновані заходи із вдосконалення структури живоплотів можуть слугувати основою подальших екологічних досліджень середовищетвірної ефективності фітоценотичного покриву урбогенних територій, та, стосовно живоплотів, мають практичне значення у проєктуванні та формуванні санітарно-захисних насаджень.

Аналіз останніх досліджень та публікацій. Роль зелених насаджень, як механічного i біологічного бар'єру пилового забруднення міської біосфери, досліджувало багато авторів $[1,3,4,7,11,14,20]$. Сучасні дослідження середовищетвірних функцій міської зелені знаходимо у дисертаційних роботах Володарець С. О (2016), Гоцій Н. Д. (2019), Денисюк Н. В. (2021). Зазвичай, такі дослідження стосуються аналізу пиловловлювання різними видами рослин.

Пилоосаджувальну властивість деяких деревних видів вуличних насаджень Чернівців, зокрема Tilia cordata Mill., Juglan regia L., Betula pendula Roth., Catalpa bignonioides Wolt., досліджували Москалик Г. Г., Чижевська Н. I. (2009).

Важлива роль у пилоочищенні міського повітря належить саме низькорослим деревам і кущам, оскільки рівень забруднення атмосфери приземних шарів значно більший. Доцільно зазначити, що пил осідає і добре затримується не тільки у фітомасі рослин, але й на грунті всередині насаджень, особливо чагарникових. За інтенсивністю пиловловлювання деревні рослини відносять до трьох груп, серед яких із кущів до першої потрапляють Philadelphus coronarius L., Ribes aureum Pursh.; до другої - Symphoricarpos albus L., Sambucus racemosa L., а до третьої - Syringa vulgaris L. [6].

Захисні властивості живоплотів досліджено у багатьох наукових роботах $[2,5,14,21]$. Встановлено іс- тотну пилозахисну ефективність живоплотів, висаджених вздовж міських автомобільних доріг, автосервісів, шиномонтажних та автозаправних станцій. При цьому, на якість седиментації пилу живоплотами впливає їх висота, структура, видовий склад, мікрокліматичні умови, ландшафтно-географічні особливості місцевості та інтенсивність автомобільного руху.

Шкода, але цінність живих огорож, їх багатофункціональність і потужні захисні властивості недооцінені. У сучасному озелененні міст мало уваги приділяють створенню живоплотів, особливо як бар'єру між вулицею і тротуаром. Тому, різнобічні дослідження пиловловлювальних можливостей живоплотів важливі як для правильного вибору асортименту видів, так і для стимулювання їх впровадження в систему міських зелених насаджень.

Матеріали та методи дослідження. Для дослідження відбирали зразки листя найпоширеніших для живоплотів цього регіону видів: свидини білої (Cornus alba (L.) Opiz., pис. 1,a), граба звичайного (Carpinus betulus L., pис. 1, b) та пухироплідника калинолистого (Physocarpus opulifolia L.), що зростали на території парків, скверів, вздовж віддалених мало завантажених селищних вулиць та у найскладніших умовах антропогенного впливу - вздовж головних вулиць Чернівців. Умовним контролем (I ЕФП) було обрано створений для експериментів живопліт у наближених до природних присадибних умовах у смт Берегомет.

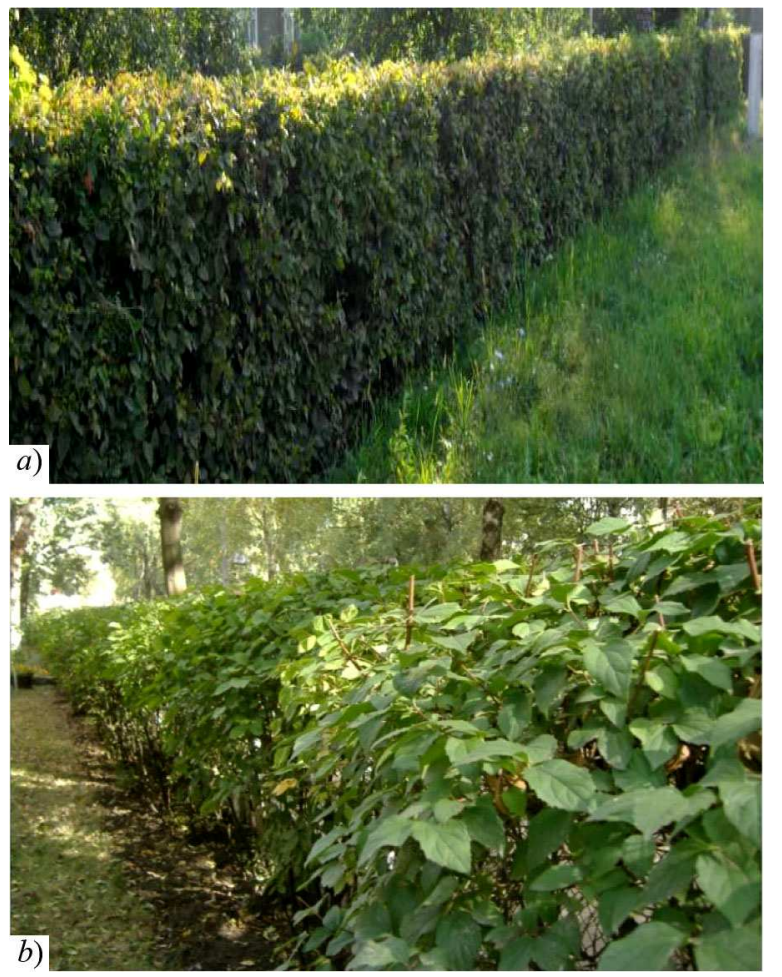

Рис. 1. Живоплоти вздовж магістральних вулиць м. Чернівці / Hedges along the main streets of Chernivtsi: $a$ ) живопліт зі свидини білої / white dogwood hedge; $b$ ) живопліт із граба звичайного / european hornbeam hedge

Нагромадженням пилу на листкових пластинках визначали шляхом відбору проб у кількості 10 шт. на кожному рівні від 20-200 см у 3-5-разовій повторюваності. Запилені листки зважували до і після змивання пилу, використовуючи вагу "МН - 200 Series Pocket Scale". Масу пилу встановлювали в мг на $1 \mathrm{~cm}^{2}$ як різницю між двома зважуваннями листків. 


\section{Результати дослідження та їх обговорення / Research results and their discussion}

Пилозахисну роль живоплотів визначали на відібраних для дослідження об'єктах, що представляли чотири еколого-фітоценотичні пояси (ЕФП) - від наближених до природних умов садиб до міської магістральної вулиці. Аналізували здатність до пиловловлювання поши- рених у складі живоплотів на Буковині видів кущів: Carpinus betulus L., Cornus alba (L.) Opiz., Physocarpus opulifolia L. Розташування та основні характеристики об'єктів дослідження наведено в табл. 1. Досліджувані живоплоти належать до простих, середніх за висотою, формованих, однорядних живоплотів зі шириною від 0,6 до 1,5 м і характеризуються добрим якісним станом.

Табл. 1. Розташування та характеристика об'єктів дослідження / Location and characteristic of the objects of research

\begin{tabular}{|c|c|c|c|c|c|c|c|c|c|c|}
\hline \multirow[b]{2}{*}{ Назва виду } & \multirow[b]{2}{*}{ ЕФП } & \multirow[b]{2}{*}{ Розташування } & \multirow[b]{2}{*}{ Ширина } & \multirow[b]{2}{*}{$\begin{array}{c}\text { Висо- } \\
\text { та }\end{array}$} & \multirow[b]{2}{*}{$\begin{array}{l}\text { Кіль- } \\
\text { кість } \\
\text { рядів }\end{array}$} & \multirow[b]{2}{*}{$\begin{array}{c}\text { Фор- } \\
\text { мова- } \\
\text { ний }\end{array}$} & \multirow{2}{*}{$\begin{array}{l}\text { Не } \\
\text { фор- } \\
\text { мова- } \\
\text { ний }\end{array}$} & \multicolumn{3}{|c|}{ Якісний стан } \\
\hline & & & & & & & & $\begin{array}{l}\text { доб- } \\
\text { рий }\end{array}$ & $\begin{array}{l}\text { за- } \\
\text { дов. }\end{array}$ & $\begin{array}{l}\text { не- } \\
\text { за- } \\
\text { дов. }\end{array}$ \\
\hline \multirow{4}{*}{ Cornus alba $\mathrm{L}$. } & $\mathrm{I}$ & Берегомет, сад & 1,2 & 1,5 & 1 & $*$ & - & $*$ & - & - \\
\hline & II & Берегомет, вул. Центральна & 1,3 & 1,7 & 1 & $*$ & - & $*$ & - & - \\
\hline & III & Чернівці, вул. Комарова, парк "Жовтневий" & 1,1 & 1,4 & 1 & * & - & $*$ & - & - \\
\hline & IV & Чернівці, вул. Героїв Майдану & 1,0 & 1,4 & 1 & $*$ & - & $*$ & - & - \\
\hline \multirow{4}{*}{$\begin{array}{c}\text { Carpinus betulus } \\
\text { L. }\end{array}$} & $\mathrm{I}$ & Берегомет, сад & 0,7 & 1,5 & 1 & $*$ & - & $*$ & - & - \\
\hline & II & Берегомет, вул. Центральна & 0,7 & 1,5 & 1 & $*$ & - & $*$ & - & - \\
\hline & III & Чернівці, вул. Чкалова, аеропорт & 0,6 & 1,5 & 1 & $*$ & - & $*$ & - & - \\
\hline & IV & Чернівці, вул. Федьковича & 1,5 & 2,1 & 1 & $*$ & - & $*$ & - & - \\
\hline \multirow{4}{*}{$\begin{array}{l}\text { Physocarpus } \\
\text { opulifolia L. }\end{array}$} & $\mathrm{I}$ & Берегомет, сад & 1,2 & 1,5 & 1 & $*$ & - & $*$ & - & - \\
\hline & II & Берегомет, вул. Славецька & 1,0 & 1,3 & 1 & $*$ & - & $*$ & - & - \\
\hline & III & Чернівці, вул. Комарова ДНЗ № 33 & 1,1 & 1,5 & 1 & $*$ & - & * & - & - \\
\hline & IV & Чернівці, Південно-Кільцева & 0,6 & 1,5 & 1 & $*$ & - & $*$ & - & - \\
\hline
\end{tabular}

Табл. 2. Пиловловлювальна ефективність живоплотів у різних ЕФП Чернівецької області / Dust-retaining capacity of hedges in different EPhB of Chernivtsi region

\begin{tabular}{|c|c|c|c|c|c|c|}
\hline \multirow{2}{*}{ Назва виду } & \multirow{2}{*}{ ЕФП } & \multicolumn{2}{|c|}{ Площа листкової пластинки } & \multicolumn{2}{|c|}{ Середня маса пилу } & \multirow{2}{*}{$\begin{array}{c}\text { Середнє пиловловлювання } \\
\text { на об'єктах }\end{array}$} \\
\hline & & $\mathrm{cm}^{2}$ & \% від контролю & $\mathrm{M} \Gamma / \mathrm{cm}^{2}$ & \% від контролю & \\
\hline \multirow{4}{*}{ Carpinus betulus $\mathrm{L}$. } & $\bar{I}$ & 37,49 & 100 & 0,00017 & 100 & \multirow{4}{*}{0,00033} \\
\hline & II & 36,17 & 96,48 & 0,00014 & 82 & \\
\hline & III & 26,66 & 71,11 & 0,00049 & 288 & \\
\hline & IV & 37,35 & 99,63 & 0,00053 & 312 & \\
\hline \multirow{4}{*}{ Cornus alba $\mathrm{L}$. } & $\mathrm{I}$ & 36,82 & 100 & 0,00010 & 100 & \multirow{4}{*}{0,00030} \\
\hline & II & 31,35 & 85,14 & 0,0003 & 300 & \\
\hline & III & 21,44 & 58,23 & 0,00035 & 350 & \\
\hline & IV & 32,19 & 87,42 & 0,00043 & 430 & \\
\hline \multirow{4}{*}{$\begin{array}{l}\text { Physocarpus } \\
\text { opulifolia L. }\end{array}$} & $\mathrm{I}$ & 41,5 & 100 & 0,00014 & 100 & \multirow{4}{*}{0,00028} \\
\hline & II & 37,17 & 89,57 & 0,00014 & 100 & \\
\hline & III & 35,97 & 86,67 & 0,00037 & 264 & \\
\hline & IV & 34,51 & 83,16 & 0,00045 & 321 & \\
\hline
\end{tabular}

Вагому роль у здатності рослинами утримувати пил відіграє фактура поверхні листкової пластинки цього виду, що утворює живу огорожу. Відомо і закономірно, що краще затримування пилу відбувається на тих листкових поверхнях, які мають більше нерівностей, матовість, гофрованість, опушеність чи смолистість. Водночас, за даними деяких дослідників [4, 12], ефект пилоздатності видів не залежить від розмірів листка. Результати власних досліджень засвідчили, що найкраща пилоутримувальна здатність на наших об'єктах характерна для живоплотів із граба звичайного (табл. 2). Простежено переважання маси пилу на його листках практично у всіх екоклинах, особливо у найзапиленіших умовах вулиці - порівняно зі свидиною і пухироплідником на 18,9 \% та 15,1 \% відповідно, що можна пояснити особливостями поверхні листкових пластинок цього виду. Тільки у сквері аеропорту по вул. Чкалова, Чернівці (II ЕФП) запиленість живоплоту із граба звичайного нижча, ніж у контролі, очевидно завдяки доброму догляду за цією територією. Отже, періодичне вологе прибирання вулиць і прибудинкових територій, дощування зелених насаджень може зменшити кількість пилу як на їх поверхні, так і в повітрі.
За результатами порівняльного аналізу акумулювання пилу на листках досліджуваних живоплотів 3'ясовано, що його кількість закономірно збільшується паралельно до погіршення екологічних умов від I до IV ЕФП. За умов найменшого урбогенного впливу досліджені живоплоти осаджували від 0,0001 до 0,00017

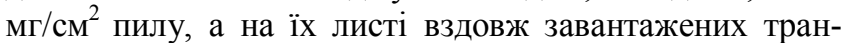
спортом міських вулиць кількість збільшується в 3,14,3 раза.

Враховуючи фактуру поверхні листкової пластинки досліджуваних видів та аналізуючи результати роботи, доцільно рекомендувати для створення живоплотів для пиловловлювання граб звичайний, який, водночас, $\epsilon$ i досить газостійким видом.

Окрім урбогенного чинника, на збільшення кількості пилу на фітомасі живоплотів впливає тип прилеглого до насадження надгрунтового вкриття. Якщо покриття дороги не $\epsilon$ асфальтованим чи вимощеним із бруківки, а кам'янистим грунтовим, то навіть за умов доброго екологічного стану довкілля (умови III ЕФП, вул. Центральна, смт Берегомет) нагромадження пилу на листі живоплоту зі свидини білої зростає у 3,5 раза порівняно 3 контролем. 
Отримані результати можуть одночасно використовуватись і як індикатори техногенного забруднення місць проживання людей у населених пунктах. Завдяки щільності структури насадження і здатності тривало зберігати нагромаджене забруднення, живоплоти стали одним із маркерів якості повітря, що дає досить реальну оцінку урбогенного навантаження (рис. 2).

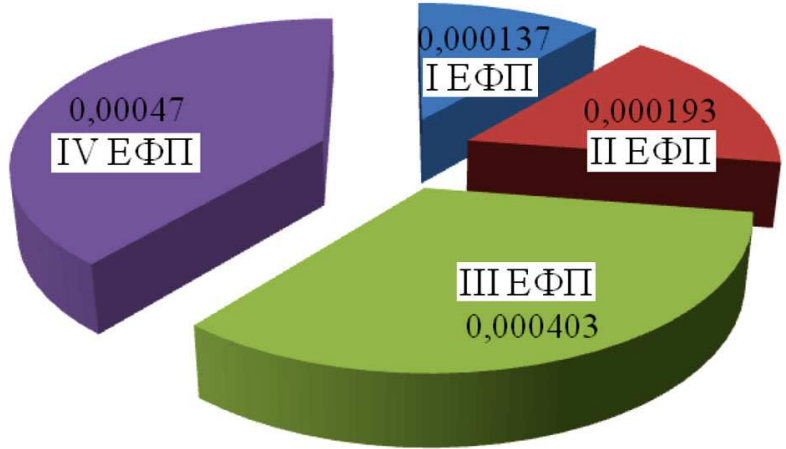

Pис. 2. Пилозатримувальна ефективність живоплотів у різних ЕФП Чернівецької урбоекосистеми $\left(\mathrm{мг} / \mathrm{cm}^{2}\right)$ / Dust-retaining capacity of hedges in different $\mathrm{EPhB}$ of Chernivtsi urban ecosystem $\left(\mathrm{mg} / \mathrm{cm}^{2}\right)$

Отже, під час створення живих огорож для пилозахисту в умовах III- IV ЕФП, доцільно використовувати види з характерною фактурою листків, які здатні затримувати та нагромаджувати часточки пилу. Невід'ємними властивостями цих видів повинні бути газо- та пилостійкість. Цим вимогам, згідно 3 нашими та дослідженнями інших авторів, відповідають граб звичайний, свидина біла, в'яз шорсткий (Ulmus glabra Huds.), дейція шорстка (Deutzia scabra Thunb.), кизильник чорноплідний (Cotoneaster melanocarpus Fisch. ex Btytt), жимолость татарська (Lonicera tatarica L.) та ін. [11]. В умовах Чернівецької області кращий пилозатримувальний ефект будуть мати живі огорожі з таких рослин: граб звичайний, свидина біла, свидина криваво-червона (Swida sanguinea L.), пухироплідник калинолистий, туя західна (Thuja occidentalis L.), липа дрібнолиста (Tilia cordata Mill.), в'яз шорсткий, клен татарський (Acer tataricum L.) та інші.

На здатність затримувати пил значною мірою впливають не тільки біометричні характеристики живоплоту, такі як висота, ширина, рядність, але і його якісний стан. Для здорової, правильно сформованої і доглянутої живої огорожі характерні добра щільність, рівномірне облистнення аж до основи, гарний профіль та однорідне забарвлення. У разі незадовільного стану в рослин у живоплоті істотно зменшується площа листя, його кількість на одиницю площі, а отже - загальна біомаса, що, поза сумнівом, впливає на кількість затримуваного пилу. Розрідження живоплоту, поява в ньому відмерлих частин рослин, ознак захворювання чи пошкодження призводять як до втрати декоративності, так і до зниження його функціональності, зокрема пилофільтрування. Тому ми розробили практичні рекомендації для покращення структури та естетичності досліджуваних живоплотів (табл. 3).

Табл. 3. Основні шляхи підвищення функціональності та декоративності живоплотів / The main ways of improving the functionality and aesthetics of hedges

\begin{tabular}{|c|c|c|c|c|c|c|c|c|c|c|c|}
\hline \multirow[b]{3}{*}{ Вид } & \multirow[b]{3}{*}{ ЕФП } & \multirow[b]{3}{*}{ Місце зростання живоплоту } & \multicolumn{9}{|c|}{ Рекомендовані заходи для покращення структури живоплотів } \\
\hline & & & \multirow{2}{*}{$\begin{array}{c}\text { Заміна, } \\
\text { онов- } \\
\text { лення, } \\
\text { рестав- } \\
\text { рація }\end{array}$} & \multirow{2}{*}{$\begin{array}{c}\text { До- } \\
\text { пов- } \\
\text { нен- } \\
\text { ня }\end{array}$} & \multicolumn{2}{|c|}{$\begin{array}{c}\text { Зміна функці- } \\
\text { онального приз- } \\
\text { начення } \\
\end{array}$} & \multicolumn{4}{|c|}{ Обрізування } & \multirow{2}{*}{$\begin{array}{c}\text { Агро- } \\
\text { техніч- } \\
\text { ні захо- } \\
\text { ди }\end{array}$} \\
\hline & & & & & Зміна & $\begin{array}{c}\text { Зміна } \\
\text { висоти }\end{array}$ & $\begin{array}{c}\text { Фор- } \\
\text { му- } \\
\text { вальне }\end{array}$ & $\begin{array}{l}\text { Сані- } \\
\text { тарне }\end{array}$ & $\begin{array}{c}\text { Ко- } \\
\text { ригу- } \\
\text { валь- } \\
\text { не }\end{array}$ & $\begin{array}{l}\text { Омо- } \\
\text { ло- } \\
\text { джу- } \\
\text { валь- } \\
\text { не }\end{array}$ & \\
\hline \multirow{4}{*}{ Cornus alba L. } & $\mathrm{I}$ & Берегомет, сад & - & - & - & - & + & + & + & - & + \\
\hline & II & Берегомет, вул. Центральна & - & + & - & - & + & + & + & - & + \\
\hline & III & $\begin{array}{l}\text { Чернівці, вул. Комарова, парк } \\
\text { "Жовтневий" }\end{array}$ & - & + & - & - & - & - & + & - & + \\
\hline & IV & Чернівці, вул. Героїв Майдану & + & + & - & - & + & + & - & - & + \\
\hline \multirow{4}{*}{$\begin{array}{l}\text { Carpinus betu- } \\
\text { lus L. }\end{array}$} & $\mathrm{I}$ & Берегомет, сад & - & - & - & - & + & + & + & - & + \\
\hline & II & Берегомет, вул. Центральна & - & + & - & - & + & + & - & - & + \\
\hline & III & Чернівці, вул. Чкалова, аеропорт & + & + & + & - & + & + & - & - & + \\
\hline & IV & Чернівці, вул. Федьковича & - & - & - & - & - & - & - & + & + \\
\hline \multirow{4}{*}{$\begin{array}{l}\text { Physocarpus } \\
\text { opulifolia } \mathrm{L} .\end{array}$} & I & Берегомет, сад & - & - & - & - & + & + & - & - & + \\
\hline & II & Берегомет, вул. Славецька & + & + & - & - & + & + & - & - & + \\
\hline & III & Чернівці, вул. Комарова ДНЗ № 33 & - & + & - & - & + & + & - & - & + \\
\hline & IV & Чернівці, Південно-Кільцева & - & + & - & - & + & + & - & - & + \\
\hline
\end{tabular}

Примітка: * - Проведення агротехнічних заходів (мульчування, полив, боротьба з фіто- та ентомошкідниками)

Для повноцінного виконання своїх функцій проаналізованим живоплотам, здебільшого, необхідно провести формувальні та санітарні обрізування, поодиноко коригувальні. Чимала частка (25\%) дослідних живоплотів потребує суцільного оновлення, тобто створення нових живоплотів, а 67 \% 3 них - доповнення у місцях втрати структурних одиниць. Агротехнічним заходам під час догляду за зеленими насадженнями, на жаль, повсюдно приділяють мало уваги. Тому всі живі огорожі потребують поливу, підживлення, заходів боротьби зі шкідни- ками та хворобами, мульчування грунту, прополювання тощо. Застосування запропонованих заходів $є$ важливими для покращення якісного стану і пилозахисних функцій живоплотів.

3 одного боку, нагромадження пилу на листках рослин сприяє очищенню повітря, а з іншого, має негативний вплив на самі рослини. Запилення листя порушує процеси транспірації, фотосинтезу, оптичні властивості листка, призводить до передчасного відмирання зеленої маси. Зменшенню запиленості як міських вулиць, так і 
листкових пластинок рослин, сприяють сильні опади. Тому дощування крон прилеглих до вулиць, особливо 3 інтенсивним рухом транспорту, насаджень, а також вологе прибирання самого полотна дороги, дасть змогу зменшити запилення приземного шару повітря і очистити листкові пластинки рослин від закупорення продихів часточками пилу.

\section{Висновок / Conclusions}

1. Ступінь запилення атмосферного повітря урбанізованих територій закономірно збільшується 3 посиленням техногенного впливу (в напрямку центр міста $\rightarrow$ заміська зона, I $\rightarrow$ IV ЕФП), що підтверджено встановленою кількістю пилу на листі рослин у живоплотах населених пунктів Чернівецької області.

2. Живоплоти створюють добрий пиловловловлювальний ефект, який залежить від будови і видового складу рослин. Усі досліджувані види рослин у живоплотах добре акумулюють пил і розташовуються у такій послідовності у бік зменшення пилозатримування: Carpinus betulus L. $\rightarrow$ Cornus alba L. $\rightarrow$ Physocarpus opulifolia L.

3. Для очищення повітря від пилу для цього регіону ефективними будуть живоплоти із граба звичайного, який акумулює найбільше пилу і є досить газо- і пилостійким видом. Перспективними також є: свидина біла, свидина криваво-червона, пухироплідник калинолистий, туя західна, липа дрібнолиста, в'яз шорсткий, клен татарський.

4. Доцільно ширше запроваджувати живоплоти в систему озеленення населених пунктів, особливо для ізоляції тротуарів від проїжджої частини.

5. Задля покращення якісного стану і функціональності живоплотів потрібно вчасно застосовувати заходи для поліпшення структури живоплотів, особливо різні види обрізувань, дотримуватись системи агротехніки створення і догляду за ними.

6. Регулярне зволоження та полив доріг міста, дощування крон вуличних насаджень покращить якість атмосферного повітря і життєздатність зелених насаджень.

Аналіз фактичного матеріалу і результатів роботи засвідчує перспективність оздоровлення середовища урбанізованих територій за допомогою зелених насаджень, зокрема живоплотів, доцільність продовження i поглиблення подібних досліджень.

\section{References}

1. Ageeva, E. A., \& Kazantseva, M. N. (2012). Otsenka pyileuderzhivayuschey sposobnosti listev derevev i kustarnikov v nasazhdeniyah g. Tyumeni. Aktualnyie problemyi lesnogo kompleksa. Bryansk, No. 31, 88-91. [In Russian].

2. Baudry, J., Bunce, R. G. H., \& Burel, F. (2000). Hedgerows diversity: an international perspective on their origin, function and management. Journal of Environmental Management, Vol. 60, 7-22.

3. Bessonova, V. P. (2001). Metody fitoindykatsii v otsintsi ekolohichnoho stanu dovkillia. Zaporizhzhia: Vyd-vo ZDU, 196 p. [In Ukrainian].

4. Buharina, I. L., Povarnicina, T. M., \& Vedernikov, K. E. (2007). Ekologo-biologicheskie osobennosti drevesnyh rastenij v urbanizirovannoj srede: monografiya. Izhevsk: FGOU VPO Izhevskaya GSKHA, 216 p. http://elibrary.udsu.ru/xmlui/bitstream/handle/123456789/6336/2010153.pdf? sequence=1

5. Burel, F., \& Baudry, J. (1995). Social, aesthetic and ecological aspects of hedgerows in rural landscapes as a framework for greenways. Landscape and Urban Planning, Vol. 33, 327-340.

6. Chernyishenko, O. V. (2001). Kriterii otsenki poglotitelnoy sposobnosti drevesnyih rasteniy v urboekosistemah. Ekologiya, monitoring $i$ ratsionalnoe prirodopolzovanie: nauchn. trudyi, 307(I), 133-140. Moscow: MGUL. [In Russian].
7. Chernyishenko, O. V. (2001). Pyilefiltruyuschaya sposobnost drevesnyih rasteniy v gorode i ee ekologicheskoe znachenie. Ekologi$y$ a, monitoring $i$ ratsionalnoe prirodopolzovanie: nauchn. trudyi, 307(1), 124-132. Moscow: MGUL. [In Russian].

8. Denysiuk, N. V. (2021). Seredovyshchetvirna efektyvnist zelenykh nasadzhen zahalnoho korystuvannia mista Rivne. Candidate Dissertation for Biology Sciences: 03.00.16; Rivnenskyi derzh. human. un-t, Instytut ekolohii Karpat NAN Ukrainy. Lviv, 204 p. http://www.ecoinst.org.ua/pdf/DenysykN-Dysertatsiia.pdf

9. Hanaba, D. V. (2015). Pylove navantazhennia na derevni nasadzhennia mista Khmelnytskoho. Visnyk Cherkaskoho universytetu. Seriia: Biolohichni nauky, 19, 55-60. http://nbuv.gov.ua/UJRN/VchuB_2015_19_9

10. Hotsii, N. D. (2019). Pylozatrymuvalna zdatnist naiposhyrenishykh lian rodu Parthenocissus Planch. Scientific Bulletin of UNFU, 29(1), 45-48. https://doi.org/10.15421/40290109

11. Ilkun, G. M. (1978). Zagryazniteli atmosferyi i rasteniya. Kiev: Naukova Dumka. 247 p. [In Russian].

12. Kabanov, A. N., Kabanova, S. A., Danchenko, M. A., \& Kochegarov, I. S. (2020). Izuchenie osobennostej vodnogo rezhima i pyleuderzhivayushchej sposobnosti kultur Betula pendula Roth. v Severnom Kazahstane. Vestnik Rossijskogo universiteta druzhby narodov. Seriya: Agronomiya i zhivotnovodstvo, 15(4), 325-334. https://doi.org/10.22363/2312-797X-2020-15-4-325-334

13. Kucheryavyiy, V. A. (1991). Urboekologicheskie osnovyi i printsipyi introduktsii i fitomelioratsii (na primere bolshih gorodov Zapada USSR). Abstract of Doctoral Dissertation for Agricultural Sciences (06.00.18 - Lesnyie kulturyi, selektsiya, semenovodstvo i ozelenenie gorodov). Moscow: Nauka, $40 \mathrm{p}$.

14. Logacheva, E. A., \& Soldatova, V. V. (2015). Pyilepogloschayuschaya rol zhivyih izgorodey, zaschischayuschih okruzhayuschuyu sredu urbanizirovannyih territoriy ot otritsatelnogo vliyaniya avtotransporta. Fundamentalnyie issledovaniya, 2(13), 28602865. https://fundamental-research.ru/ru/article/view?id=37575

15. Lyubimov, V., Melnikov, I. V., Melnikov, E. V., \& Soldatova, V. V. (2015). Zaschitnyie funktsii drevesno-kustarnikovyih rasteniy, shiroko vvedennyih v ozelenenie Bryanskoy oblasti i ih rekomenduemyie tipyi posadok. Vestnik Bryanskogo gosudarstvennogo universiteta. Seriya: Tochnyie i estestvennyie nauki, No. 3, 395398. http://vestnik-brgu.ru/wp-content/numbers/v2015 2.pdf

16. Maslov, N. V. (2003). Gradostroitelnaya ekologiya. Moscow: Vyisshaya shkola, 30-31. [In Russian].

17. Moskalik, G. G., \& Chizhevskaya, N. I., (2009). Pylenakopitelnaya sposobnost nekotoryh drevesnyh porod $v$ usloviyah goroda. Retrieved from: http://www.rusnauka.com/13 EISN_2009/Ecologia/45577.doc.htm

18. Nikolaevskiy, V. S. (1979). Biologicheskie osnovyi gazoustoychivosti rasteniy: monografiya. Novosibirsk: Nauka. [In Russian].

19. Osipova, N. V. (1984). Ohrana okruzhayuschey sredyi sredstvami ozeleneniya. Pushkino. 123 p. [In Russian].

20. Tarabrin, V. P. (1974). Ustojchivost drevesnyh rastenij v usloviyah promyshlennogo zagryazneniya. Abstract of Doctoral Dissertation for Biology Sciences, Kiev, 54 p. [In Russian]

21. Vinnikov, Y. U. A. (2010). Razrabotka shumozashchitnyh metodov s primeneniem zelenyh nasadzhenij pri razvitii selitebnyh territorij gorodskoj zastrojki: Abstract of Doctoral Dissertation for Technical Sciences (05.23.22 - Gradostroitelstvo, planirovka selskih naselennyh punktov), Moscow: Nauka, 22 p. file://C:/Users/Dell.000/Downloads/autoref-razrabotka-shumozashchitnykh-metodov-s-primeneniem-zelenykh-nasazhdenii-prirazvitii-seliteb.pdf

22. Volodarets, S. O. (2016). Sanuiucha funktsiia derevnykh roslyn kulturfitotsenoziv urbanizovanoho seredovyshcha. Abstract of Doctoral Dissertation for Biology Sciences avtoref (03.00.16), Dnipropetr. nats. un-t im. Olesia Honchara. Dnipro, 23 p. http://www.dnu.dp.ua/docs/ndc/dissertations/D08.051.04/autoreferat $57 \mathrm{fe} 2 \mathrm{ce} 55 \mathrm{f} 9 \mathrm{bf} . \mathrm{pdf}$

23. Zhumadilova, A. Zh. (2016). Pyileuderzhivayuschaya sposobnost drevesnyih i kustarnikovyih rasteniy. Novosti nauki Kazahstana http://www.vestnik.nauka.kz/selskoe-i-lesnoe-xozyajstvo/pyleuderzhivayushhaya-sposobnost-drevesnyx-i-kustarnikovyx-rastenij.php 


\section{DUST RETENTION FUNCTION OF HEDGES: THE CASE STUDY OF URBAN ECOSYSTEMS IN CHERNIVTSI REGION}

Intensive processes of urbanization contribute to a significant deterioration of the environment, its pollution by harmful and toxic substances, and also complicating the living conditions of residents. An effective way to improve the environment is the creation of green spaces for various purposes, such as a dust protective barrier in particular. Hedges are integral elements of urban and suburban landscaping which make a significant contribution to both the aestheticization of the environment and the solution of its environmental problems. The dust-retaining capacity of hedges formed from the most common species of woody plants was studied: white dogwood (Cornus alba (L.) Opiz.), European hornbeam (Carpinus betulus L.) and common ninebark (Physocarpus opulifolia L.), which grow in parks, garden squares, along remote low-traffic village streets and in the rough conditions of anthropogenic impact - along the main streets of Chernivtsi. By means of conditional control (EPhB I), a hedge created for experiments was chosen in close to natural household plot conditions in the urban-type settlement of Berehomet. The accumulation of dust on leaves was determined by weighing dirty and clean leaves of 10 selected samples at each level from 20 to $200 \mathrm{~cm}$ above the ground in 3-5 times of repeatability. The investigated hedges belong to typical mean height hedges, these are single-row hedges 0.6 to $1.5 \mathrm{~m}$ in width and are characterized by good quality condition. Comparative analysis of dust accumulation on the leaves of the studied hedges showed that its amount naturally increased in parallel with the deterioration of environmental conditions from I to IV EPhB. Under conditions of the least urbogenic influence, the studied hedges retain from 0.0001 to $0.00017 \mathrm{mg} / \mathrm{cm}^{2}$ of dust, and the amount of dust accumulated on their leaves along the city streets with heavy traffic increases by 3.1-4.3 times. A high level of dust sedimentation on leaves of all the studied species was found, this is especially true for Carpinus betulus, since the species has a complex texture of the leaf surface. The increase in the amount of dust on the phytomass of hedges is noticed to be influenced by the type of ground cover adjacent to the planting. Some recommendations have been developed regarding the species composition of hedges that are promising in terms of dust retention and technological methods for improving their functional ability and quality condition. The expediency of wider introduction of hedges into the greening system of settlements as indicators of technogenic pollution and a powerful dust barrier has been substantiated.

Keywords: hedge; dust retention; sedimentation; urbanized environment; urbogenic influence. 